\title{
THE ANALYSIS OF NON-LITERAL MEANING IN CHRISTMAS CAROL BY CHARLES DICKENS
}

\author{
Maria Salvatrix B.B. Nimanuho \\ elfreea@gmail.com \\ English Literature Department, Faculty of Language and Literature \\ University of Kanjuruhan Malang
}

\begin{abstract}
This study investigates non-literal meaning in 'Christmas Carol' story written by a famous British author, Charles Dickens. This study used a descriptive qualitative method. The data were taken or collected from words, phrases, and sentences on 'Christmas Carol' novella, without reducing, adding, or changing any parts from the original source. The data were analyzed to answer three research questions: (1) What types of non-literal meaning are found in Christmas Carol story? (2) What are the interpretations of those non-literal meanings found in Christmas Carol story? (3) What is the most dominant type of non-literal meaning found in Christmas Carol story? In order to avoid bias, validator triangulation was used. The study found 11 idiom, 14 Simile, 6 Hyperbole, 6 Alliteration, 5 Personification, 3 Anaphora, 3 Onomatopoeia, 2 Irony, 2 Synecdoche, 2 Sarcasm, 1 Metaphor, and 1 Litotes. Simile was the non-literal meaning's type which was mostly used in the story, although the percentage was still less than 50\%. These findings indirectly could help the readers to understand deeper the message or the story that the author wants to convey. It is suggested for future researchers to investigate the non-literal meaning of others literary works such as tale, folklore, fairy tale, short-story, fable, etc. and media such as movie, drama, speech script etc. It is because other type of non-literal meaning and different ways of using them could be found in these literary works and media. This study will improve our understanding about non-literal meaning.
\end{abstract}

Keywords: Semantics, Non-Literal meaning, Christmas Carol, Novella, Charles Dickens

\section{INTRODUCTION}

People interact and communicate each other using language which makes language as the most important tool in people's life, as stated by Fernandez and Wiley (2010: 6): "Language is a formal system for pairing signal with meaning". Since language is that important, there are many fields which concern about language study, one of them is Linguistic. Semantics is one of Linguistic branches which, "is the tend to read the original story with the original language since that is good for improving our English, but sometimes difficulties are still found.

English literary works, specifically those which were written under $80^{\prime}$ use old English containing many figure of speech which makes the story difficult to understand and enjoyed, especially for non-English native speaker. One of the examples is Christmas Carol, a very famous Christmas tale which was published in 1843. This story is one of the best works by a well-known British 
study of meaning in language" (Hurford, Heasley, and Smith, 2007:1) since meaning has many varieties which can be found in daily life, such as daily conversation, speech, drama, and literary works.

Literary works is something very familiar and getting popular even though people now are living in a globalization era which relatively close to internet and online activities. Literary works can be enjoyed by many people from different cultures and classes. The most everlasting form of Literary work is prose, especially novel, novella, and short story. These kinds of literary works cannot be vanished or replaced. According to the history, it is well known that Literary works come mostly from British people. British literary works and artists are well known all over the world, including in Indonesia. Their proses, poems, and dramas indirectly influence and inspire other countries' literary works, especially America and the others English-speaking country.

Literary works from Englishspeaking countries have spread broadly also impact Indonesian people who love reading. Their novel and shortstory has become one of the most favorite and best seller reading in Indonesia. Many of their literary works are translated. Despite that there are many translated works, some people still need and

clear that Semantics is a branch of linguistics which relates to meaning. In addition, Leech (1981) says that semantics is the basic for communication study and it becomes important to learn since communication gets crucial in social organization. Therefore, Semantics author, Charles Dickens. It contains many terms of old English and a lot of non-literal meaning.

Non-literal Meaning has hidden meanings that need more interpretation to be understood. It is a "sort of meaning goes beyond literal meaning and entailment relationships based on truth conditions and involves aspects of the context of the utterances and intentions of the speaker" (Hurford, Heasley and Smith, 2007: 327). To understand the words, phrases, or sentences containing this kind of meaning, we need to know about the types of the non-literal meaning it self and the context of the story and situation.

The analysis of Non-literal meanings found in an English literary work helps the readers easier to interpret the real meaning and understand and enjoy the story better.

\section{LITERARY REVIEW Semantics}

There are some definitions of semantics proposed by the linguists such as stated by Hornby (1974: 775), "Semantics is branch of linguistics concerned with studying the meaning of sentences and words", so it is

\section{Connotative Meaning}

Connotative meaning is the communicative value of an expression over and above its purely conceptual content. It is something that goes beyond mere referent of a word and hints at its attributes in the real world and more than the dictionary word. One word can have many interpretations and many words can refer to only one meaning.

Social Meaning

The meaning that depends on where an utterance takes place is called Social Meaning. The decoding of a text is 
has developed and became a worthy study since meaning is strictly connected to communication.

\section{Meaning}

Based on some experts, there are some opinions about meaning one of them is meaning "as a situation in which the speakers utter it and response which it calls forth in the hearer" (Bloomfield, 1933: 139). All communication has meaning that is understood by the communicator. What the $1^{\text {st }}$ person (speaker) said will be accepted by another person who will translate that back into the idea, and that's how the $2^{\text {nd }}$ person (receiver) understands and knows what the $1^{\text {st }}$ person means.

\section{Varieties of Meaning}

Linguists have classified meaning from different point of view based on their deliberations, such as follow;

\section{- Leech's Seven Types of Meaning} In his 'Semantic- A Study of meaning' (1981) book, he breaks down meaning into seven types namely,

\section{Conceptual Meaning}

It is also called logical or cognitive meaning. It is the basic propositional meaning which corresponds to the primary dictionary definition. It is the literal meaning of the word indicating the idea or concept to which it refers to and deals with the core meaning of expression.

\section{. Non - Literal Meaning}

Hurford, Heasley, and Smith (2007) on their book "Second edition : Semantic, a course book", explain non-literal meaning as "sort of meaning goes beyond literal meaning and entailment relationships based on dependent on our knowledge of stylistics and other variations of language and it is concerned with the social circumstances of the use of a linguistic expression.

\section{Effective Meaning}

It is what is conveyed about the personal feelings or attitude towards the listener. In affective meaning, language is used to express personal feelings or attitude to the listener or to the subject matter of his discourse.

\section{Reflected Meaning}

At the lexical level of language, it arises when a word has more than one conceptual meaning or multiple conceptual meaning. Reflected meaning can be found in taboo words.

\section{Collocative Meaning}

Collocative meaning is the meaning which a word acquires in the group of certain words. Collocative meaning refers to associations of a word because of its usual or habitual co-occurrence with certain types of words

Thematic Meaning

It refers to what is communicated by the way in which a speaker or a writer organizes the message in terms of ordering focus and emphasis. Thus, active is different from passive although its conceptual meaning is the same.

Figurative language uses figures of speech, a way of saying something other than the literal meaning of the words.

\section{Kinds of Figurative Language}

Hyperbole 
truth conditions, and involves aspects of the context of the utterance and intentions of the speaker" (p.327). It evokes what has traditionally been called 'figurative' or 'non-literal' meaning: in particular, idiomatic or fixed expressions, metaphor, and metonymy. Meanwhile, Siregar (1992:10) says, "We sometimes mean something different from what our mean, in other words, we sometimes speak non-literally".

\section{Idiom}

Idiom is a group of words that means something different than the individual words it contains. It is created by the addition of color and texture to language by creating images that convey meanings beyond those of the individual words that make them up (Balls, 2010). For example; He kicked the bucket which actually means 'He died'.

\section{Figurative Language}

According to Wren (1981: 488), "Figurative expression is a departure from the ordinary form of expression or the ordinary course of ideas in order to produce a greater effect", which is means it is an expression that can be substituted or replaced by the variations of points which successfully to imply the same meaning by giving an effect greatly different from what it literally. Beckson and Ganz (1975) also state that Figurative language is language which contains what is called figure of speech. Most of which are techniques for comparing dissimilar objects, to achieve effects beyond the range of literal language.
Hyperbole is a big exaggeration in expressing something (Kennedy, 1978). Exaggerated way is an expression to make something bigger or greater than it really is.

Metaphor

Is a mapping between two things which is used for an expression to compare two unlike objects without using 'like' or 'as' (Tarigan, 1985).

$\underline{\text { Simile }}$

Based on Kennedy (1978), a simile is "a comparison of two unlike things, typically indicated by some connective, 'like' or 'as'." (p. 487). The words simile and similar are derived from the same Latin word, 'simile' means 'like'.

\section{$\underline{\text { Litotes }}$}

Litotes means saying less than is actually the case. Litotes, according to Tarigan (1985) "is a figure of speech which contains an expression which is less in expressed than the original fact" (p. 58). In other words, a figure of speech consisting of an understatement in which an affirmative is expressed by negating its opposite.

\section{Personification}

Personification means giving an inhuman thing human qualities as Barnwell (1980) says that Personification is a figurative language which is things or abstract idea are given the human behavior.

Irony

According to Galperin (1977: 146) is "a stylistic device also based on the simultaneous realization of two logical 
Meaning - dictionary and contextual, but the two meanings stand in opposition to each other."

Alliteration

Alliteration is the easiest of the examples of figurative language to spot (Keraf, 1991). It is a repetition of the first consonant sounds in several words.

\section{Onomatopoeia}

The use of words that sound like their meaning, or mimic sounds (Keraf, 1991). They add a level of fun and reality to writing.

\section{Synecdoche}

A kind of figurative expressions which is a particular form of metaphor, states one thing partly instead of its universe or vice versa (Mezo, 1999). So to mention the whole thing, we can expresses with the little part of it.

$\underline{\text { Sarcasm }}$

It is a term in rhetoric and general use for sneeringly ironical remarks (McArthur, 1996). It expresses something with a rude way.

\section{Anaphora}

Anaphora is repeating a sequence of words at the beginnings of neighboring clauses, and it means to give emphasis. Usually it is mostly found on poem or rhyme.

\section{Allegory}

Allegory is a story, painting or description in which ideas such as patience, purity and truth are symbolized by persons who are characters in the story.

\section{Allusion}

Allusion is the process of referring to figures or events in life or in literature that are known. It also said a brief and indirect reference to a person, place, thing, or idea of historical, cultural, literary or political significance.
Anti-thesis

Anti-thesis is when two or more strongly contrasting terms are presented together Epiphora

The repeating ends of neighboring clauses aim is also to give emphasis. So, the repeated words are the words come in the end.

\section{Euphemism}

Euphemism is the use of other mild, vague and indirect words or phrases in place of what is required by truth or accuracy

Imagery

Imagery is images, picture, or sensory content which we find in a poem

Metonymy

Metonymy is the substitution of word closely related with another word in place of that words

Paradox

Is often used to make readers think over an idea in innovative way. It is also used to illustrate an opinion or statement contrary to accepted traditional ideas.

\section{Satire}

It is a figure of speech to tease something or persons by using another way to express. It's function not to make people laugh or make fun, but intents to warn.

\section{Literature}

Borges (2007) explains Literature as "all creative writings of recognized artistic value, a body of written works related by subject-matter (e.g. the literature of computing), by language or place of origin (e.g. Russian literature), or by prevailing cultural standards of merit" (p.18). Since the 19th century, the broader sense of literature as a totality in form of written or printed works has given way to more exclusive definitions based on criteria 
of imaginative, creative, or artistic value, usually related to a work's absence of factual or practical reference. Even more restrictive has been the academic concentration upon poetry, drama, and fiction.

\section{Prose}

Prose consists of writing that does not refer to any particular formal structures (other than simple grammar). The term sometimes appears pejoratively, but prosaic writing simply says something without necessarily trying to say it in a beautiful way, or using beautiful words (Borges, 2007).

Length often serves to categorize works of prose fiction as follow;

A Mini Saga is a short story of exactly 50 words

A Flash fiction is generally defined as a piece of prose under a thousand words.

A short story comprises prose writing of less than 10,000 to 20,000 words, but typically more than 500 words, which may or may not have a narrative arc.

A story containing between 20,000 and 50,000 words falls into the novella category.

A work of fiction containing more than 50,000 words falls squarely into the realm of the novel.

\section{Christmas Carol}

A Christmas Carol is a long story of the kind called a novella since it is too big for a short-story but too short to be a novel (Moore, 2004). It was written in 1843 , the first of a series of what was called Christmas Books and also was first published on December 19, 1843.

\section{RESEARCH METHOD}

\section{Research Design}

This study used Qualitative Research since it was conducted by using descriptive analysis without statistical analysis. The researcher analyzed the data which were taken naturally without reducing, adding, or changing anything from the data source. Miles and Huberman (1994) also stated that "Qualitative research is conducted through an intense and/or prolonged with a 'field' or life situation" (p.6) which is mean that it is based on natural condition without any setting or change. It also research used nonparticipant interview and content analysis since there is no participant to be interviewed and this research analyzed the content from the data source.

\section{Data source}

The PDF e-book by Jose Menendez, with additional illustration by John Leech "A Christmas Carol in Prose, Being a Ghost Story of Christmas" written by Charles Dickens.

\section{Procedure of Data Collection}

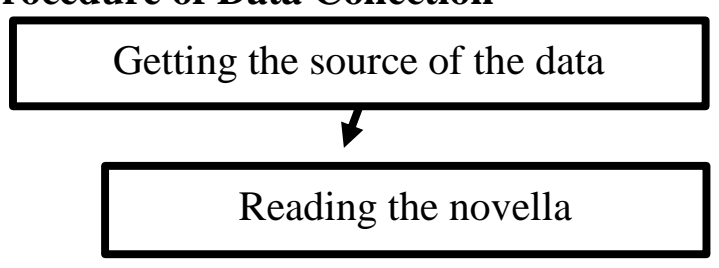


It quickly became popular and influenced the way people in Britain think of Christmas.

Re-reading the specific chapter if necessary to get better understanding

Finding out and underlining the words, phrases, and sentences containing non-literal meaning

$+$

Classifying and analyzing words, phrases, and sentences containing non-literal meaning

\begin{tabular}{|ll|}
\hline $\begin{array}{l}\text { The type of } \\
\text { non-literal meaning }\end{array}$ & Frequency \\
Simile & 14 \\
Metaphor & 1 \\
Hyperbole & 6 \\
Personification & 5 \\
Alliteration & 6 \\
Onomatopoeia & 3 \\
Litotes & 1 \\
Irony & 2 \\
Synecdoche & 2 \\
Sarcasm & 2 \\
Anaphora & 3 \\
Idiom & 11 \\
\hline
\end{tabular}

Interpreting the meaning of words, phrases, and sentences which contain nonliteral meaning

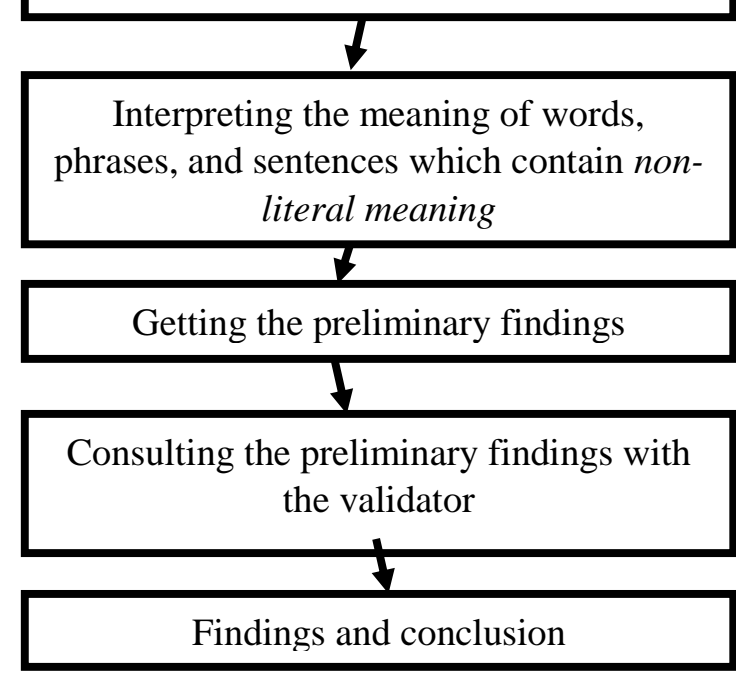

Classifying words, phrases, and sentences containing non-literal meaning based on their types on non-literal meaning

Identifying the number of each type of non-literal meaning

\section{Triangulation}


This study analyses words, phrases, and sentences containing non-literal meanings which are found on Christmas Carol story and so to make sure that the findings are accurate, a validator is needed. Triangulation is used to achieve results in which the variance that is obtained reflects the measurement of the trait being studied (Burns \& Grove, 2001).

\section{FINDINGS AND DISCUSSION}

\section{Findings}

Many words, phrases, and sentences which containing non-literal meaning are found after doing the data analysis. Total are 51 data, consists of 11 types of figurative language and Idiom with the classification as the table ;

that is contained in the phrase the old bell was always peeping slily wond at Scrooge as Personification as what stated that Personification is figurative language which is things or abstract idea are given the human behavior (Barnwell; 1980). After classifying, author then see the context of the story. The sentence is used to describe Scrooge's characteristic which had been explained that he was a cold, stingy, and individualism person. By looking up the definition and the context, the phrase old bell was always peeping slily down at Scrooge can be understood as 'Scrooge never went to the church or even paid attention again in his old age.' He just always passed the church without entering it and also barely did the charity. That is why the church's bell "looked at" him when he walked around like questioning him "why did he never come in? Why he just passed?".

All the data were analyzed using the method. Since all the processes were conducted by the author herself, that is why Validator Triangulation is used to avoid the bias of the data analysis.

\section{$\underline{\text { Discussion }}$}

intention to the context of the story and where the conversation took place and situation in. For example;

The ancient tower of a church, whose gruff old bell was always peeping slily down at Scrooge...(p.13)

The sentence above found in page 13. As what had been known that the old bell of a church is a thing, so it cannot peeping or looking down at someone. By the illustration, we can included the non-literal meaning

dominant. The percentage between the highest, the second, and the middle is not big. Simile has $27.4 \%$ and Idiom 21.5\%. Besides, the percentage of Simile as the type with the highest percentage is still under $30 \%$.

Simile, which is one of the type of figurative language, was used as the dominant type of nonliteral meaning, perhaps by several possible reasons. The use of Simile is very useful to describe the main character and emphasize his strong behavior. By comparing the character with other things which both have something in common, the character will be strongly remembered by readers. Besides, the use of Simile also can beautify the sentences.

The findings of this study are related to the some theories about non-literal meaning by some experts. Beckson \& Ganz (1975:80) says that "Figurative language is language which makes use of certain devices called figure of speech." According to those experts, there are 20 types of figurative language. Out of the twenty types, this present study found only 11 types found on the story. The 11 types includes Simile, Hyperbole, Alliteration, Personification, Onomatopoeia, Anaphora, Irony, Synecdoche, Sarcasm, Litotes, and Metaphor. Most of the types of figurative language are techniques for comparing 
51 words, phrases, and sentences containing non-literal meaning consist of 11 types of figurative language and idiom were found in 'Christmas Carol' novella. From those all types, Simile was used the most in the novella. Simile occurs 14 times with 27.4 of percentage, followed by idiom which occurs 11 times with 21.5 of percentage, Anaphora and Onomatopoeia are in the middle with 5.9 of percentage, and Litotes and Metaphor are the least with 1.10 of percentage.

From the findings, it can be concluded that there is no type of non-literal meaning specifically

16 Metaphor, 7 Simile, 7 Personification, and 1 Irony, with Metaphor as the dominant type. The findings of Sipayung's study and this present study is not exactly the same. On Sipayung's there were only 5 types of nonliteral meaning, out of 6 types he had mentioned on his Review Literature on chapter II. Meanwhile this study found 12 types include idiom. The dominant type found on both studies also are different. Sipayung's study find out that Metaphor as the dominant type, meanwhile this study find Simile as the dominant type. Even though the type are different, both of them compare two different things. It support the theory that most of the types of figurative language are techniques for comparing dissimilar objects such as Metaphor and Simile (Beckson \& Ganz, 1975). The findings of this study are also in line with what Hurford, Heasley, and Smith (2007) stated about non-literal meaning in their book "Second edition: Semantic, a course book" that non-literal meaning is "Semantic phenomena that evokes right now" (p.327) and "the study of non-literal meaning has become much more important in recent years, partly because semanticist have begun realize how prevalent it is in everyday language" (p.328). Besides, the findings of Sipayung's study and this present study also show that the different genre does not dissimilar objects such as Metaphor and Simile (Beckson \& Ganz, 1975). Therefore, they are used often. This statement is proven in this analysis of non-literal meaning in 'Christmas Carol, which is the object of this present study. This present study's findings extends the finding of previous study conducted by Sipayung (2013). On his study entitled "An Analysis of Non-Literal meaning in 'The Pearl' by John Steinback", he also found words, sentences, or phrases containing non-literal meaning. He found 9 Hyperbole,

book, or daily dialog etc. Therefore, studies about non-literal meaning with different source of the data are still needed to show that this kind of meaning is getting important nowadays.

\section{CONCLUSION AND SUGGESTION}

\section{Conclusion}

This study investigates non-literal meaning on 'Christmas Carol' story written by a famous British author, Charles Dickens. Types of nonliteral meaning found in the story consist of 11 idiom, 14 Simile, 6 Hyperbole, 6 Alliteration, 5 Personification, 3 Anaphora, 3 Onomatopoeia, 2 Irony, 2 Synecdoche, 2 Sarcasm, 1 Metaphor, and 1 Litotes. Simile was the dominant type in the story, but the percentage was less than 50\%. Yet, there was no type of non-literal meaning specifically dominant on the story.

\section{Suggestion}

It is suggested to other researchers to conduct more studies about non-literal meaning with different source of data. It is because there are still possibilities that non-literal meaning can be found in other sources. 
guarantee the different use of non-literal meaning. Both studies found non-literal meaning especially figurative language on both literary works from different genre, American and British/English Literature Despite that this study is the extension of some previous studies about non-literal meaning, future studies about this aspect are still needed. The object of this study and previous study are still in literary works whereas there are still possibilities that nonliteral meaning can be found in another source of literary works and media such as speech script, movie, conversation, education-

\section{BIBLIOGRAPHY}

Ary Donald. 2000. Introduction to Research in Education, Translated by Arif Furchan. Jakarta. Usaha Nasional. Jakarta Wadswroth

Abhrams, M.H. 2005. A Glossary of Literary Term. 8th Ed. Boston: Thomson Ball Elizabeth. 2010. in the Loop: A Reference Guide to American English Idioms.

Wangshiton. The Office of English Language Programs

Barnwell Katherine.1980. Introduction to Semantic and Translation. Horsley Green: Summer Institute of Linguistics.

Beckson and Ganz. 1975. Literary Terms: A Dictionary. Farrar, Straus, and Grous Paperback

Bloomfield L. 1933. Language. New York. Holt, Rinehart and Winston.

Borges Leila. 2007. British Literature \&American Literature. Rio de Janeiro. Centro Universitario Da Cidade

Creswell John W. 2009, Research Design, USA, Sage Publications

Dawson, et al. 2014. English Literature vs American Literature. Retrieved from http://www.differencebetween.com/difference-between-english-literature-and-vs-

american-liter/ (Accessed on 9 PM, January 20, 2016) and http://www.collegetermpapers.com/viewpaper/1303366785.html (accessed on $7 \mathrm{PM}$, January 20, 2016) 
Galperin I. R.1977. Stylistics. Moscow: Higher School

Hornby A.S. 1974. Oxford Advance Learner's Dictionary 7th Edition. London: Oxford University Press

Hurford James R., Heasley Brenda, and Smith Michael B. 2007, 2nd edition Semantic; A course book. Cambridge. Cambridge University Press

Kennedy X.J. 1978. Literature: An Introduction to Fiction. Boaton Taranto: Little and Brown Company Utama

Keraf Gorys. 1991. Diksi dan Gaya Bahasa. Jakarta: PT. Gramedia Pustaka

Leech Geoffrey. 1981. Semantics; The Study of Meaning 2nd edition. Middlesex. Penguins Books

Leedy Paul, 2005. Practical Research and Design, New Jersey.

Marzial Frank. 2005. The Life of Charles Dickens. Retrieved from The Project Gutenberg eBook, Life of Charles Dickens, by Frank Marzials

Mezo Richard E. 1999, Fire'i the blood; A handbook for Figurative Languages. USA. Universal Publisher

Miles Matthew B and Huberman, A. Michael. 1994. Qualitative Data Analysis. USA, Sage Publications Rosdakarya

Moleong Lexy J. 2005. Metodologi Penelitian Kualitatif. Bandung: Remaja

Moore Andrew. 2004. A Christmas Carol. Retrieved from http://www.universalteacher.org.uk/gcse/xmascarol.htm (accessed on 7 PM, February 10, 2016)

Ollila Bernie and Jantas Joe. 2006. The Definition of Poetry. Retrieved from http://www.joejantas.files.wordpress.com/2011/04/the-definition-of-poetry1.pdf (accessed on 6.04 PM, January 22, 2016)

Palmer F.R. 1976. Semantic; 2nd edition. Cambridge. Press Syndicate of the University of Cambridge Press

Reaske, Christopher R. 1976. How to analyze Poetry. Harvard Univ. Monarch 
Siregar Ras. 1992. Bahasa Perk Bahasa Indonesia Jurnalistik; Kerangka Teory Dasar. Jakarta. Grafikatama Jaya

Tarigan Henry Guntur. 1985. Pengajaran Semantik. Bandung: Angkasa.

Wren P. C. and H. Martin. 1981. High School English Grammar and Composition. (Revised Edition). New Delhi: S. Chand \& Company Ltd. https://en.wikipedia.org/wiki/A_Christmas_Carol (accessed on 8 PM, February 10, 2016) 